\section{Who's Paid What}

Sin,-With reference to your observations on the recent salary survey of the Royal Institute of Chemistry and related professional bodies (Nature, 220, 211; 1968), the comments you make are, I think, quite misleading. Unlike the full surveys, you appear to consider only median salaries. This causes, for example, the modian for chemists in central government, ago 26-30, to be $£ 1,640$, whereas the SSO grade (persons age on appointment 26-31) has a salary scale $£ 1,866-£ 2,306$, excluding London weighting. Clearly many chemists in central government are not on the SSO scale, but in other grades which lower the median. Considering, now, university staff, it might be reasonable to equate at age 30 the lecturer grade with SSO as requiring people of comparable ability. If this is so, comparison with the median salaries in industry, or central government, is quite misleading as the above figures show. A comparison might have been more realistic if in universities there was a comparable proportion of lower grades with a level of ability which qualified them for membership of the professional institutions. Such people would be mainly equivalent to technical officers and the like, of whom at present there are relatively few in universities.

If you consider that university staff as a whole should have no better median salary than the median in industry, perhaps you would make your arguments for this clear in your columns. If, however, you accept that the scientific officer scales of the civil service are a more acceptable comparison, I would point out that the career grade in the civil service (PSO) is much better than that in universities, which the National Incomes Commission took to be the lecturer grade, rising to a maximum of $£ 2,630$ at age 40 , and for whom further promotion is limited by a quota of 35 per cent of the total academic staff.

\section{Yours faithfully,}

123a Captains Road,

$$
\text { B. R. MALCOLM }
$$

Edinburgh 9.

\section{Why do Students Fail?}

Sir,--Mr Owens in his letter on "Why do Students Fail ?" (Nature, 220, 517; 1968) raises some important points which have been and are being widely discussed. But one cannot allow his last paragraph to pass without comment.

I cannot claim to speak for every university, but $I$ am sure that for the vast majority it is complete nonsense to statc: "It is the university administrators who make the decisions on dismissing students and the acadomics who supply the courses. Maybe if there were more cooperation between the two, failure rates would go down". At Bristol (and I am confident at most universities) these decisions are made by the boards of faculties which are composed entirely of academics under the chairmanship of the dean of faculty. Even in the least domocratic university of which I have knowledge, the decision is taken by the dean after consultation with the head of department. If $\mathrm{Mr}$ Owens classes the deans as university administrators he should remember that in British universitics deans are academics on whom the temporary (and often heavy) load of faculty administration has been imposed. There are, I belicve, few schizophrenics among us, and in coming to decisions on the progress of students, what is best for the student's future, both academic and personal, is given overriding consideration.

Yours faithfully, D. H. EveretT

School of Chemistry,

The University,

Cantock's Close,

Bristol 8.

\section{University News}

Professor O. T. Solbrig, Michigan, has been appointed professor of botany in Harvard University.

Dr Peter Kunkler, Welsh National School of Medicine, Cardiff, has been appointed professor and head of the Department of Radiotherapy in the University of Leeds.

Dr G. Matthews, Nuffield Foundation, has boen appointed to the Shell chair of mathomatics education tenable at Chelsea College of Science and Technology. The title of professor of bacteriology has been conferred on Dr C. H. Lack in respect of his post at the Institute of Orthopaedics.

Professor Paul E. Gray of the Department of Elcctrical Engineering has been appointed Class of 1922 Professor at the Massachusetts Institute of Technology. He succeeds Professor John Wulff of the Department of Metallurgy and Materials Science who retired in June.

Dr A. M. Thomson has been appointed to a personal professorship in social obstetrics in the University of Newcastle upon Tyne.

\section{Appointments}

Dr A. A. Moss has been appointed keeper of mineralogy and Dr J. D. H. Wiseman deputy keeper of mineralogy in the British Museum (Natural History).

Dr W. W. Rubey, California, has been appointed director of the Lunar Science Institute in Houston, Texas. The chief objective of the institute, which was established in March this year, is to provide a base for scientists taking part in the lunar exploration programme, working in the Lunar Receiving Laboratory or using other facilities of the Manned Spacecraft Centre devoted to study of the moon.

\section{Announcements}

The Geological Society of America has awarded the Penrose Medal to Professor John Tuzo Wilson, professor of geophysics in the University of Toronto, for his research in pure geology. The Arthur L. Day Medal has been awarded to Dr F. J. Vine of the Department of Geological and Geophysical Sciences at Princeton University, for his contributions to geological knowledge made through the application of physies and chemistry to geological problems.

Dr F. J. C. Roe has been awarded a gold medal by the scientific council of Centro Sociale Studio Precancerosi in recognition of his research in the field of carcinogenesis. The medal was presented on October 5 during the second International Seminarium on Cancer Prophylaxis.

ERratum. In the advertisement under the heading "H'inite Differences" on page xxv of this issue, A Treatise on Differential Equations by A. R. Forsyth costs $£ 1$ 15s; the edition of Theoretical Hydrodynamics by L. M. MilneThomson which has just been published is the fifth edition and costs $£ 55 s$.

Erratum. In the News and Views article "Dividends for Societies" (Nature, 220, 5; 1968) it was wrongly stated that the Fulmer Research Institute was in Sussex. It is, of course, in Stoke Poges, Buckinghamshire.

HrRatum. In the obituary notice of Professor J. E. Harris (Nature, 220, 626; 1968) it was incorrectly stated that Professor Harris died on July 1, 1968-he died on June 24. 